\title{
Akademide Kadın: Farklı Disiplinlerden Kadınların Akademideki Yeri ve Aile Yaşamlarıyla Etkileşimi
}

\author{
Women in Academia: The Situation of Women in Academia and Its \\ Interference with Their Domestic Life
}

Songül DEMİ*

\section{Öz}

Günümüz Türkiye’sinde akademik hayat, cinsiyet farkı gözetmeksizin tüm öğretim üyelerini etkileyen birçok sorunu beraberinde getirmektedir. Ancak, kişiye özel, cinsiyete ve toplumsal cinsiyete ait kimi sorunlar doğrudan kadınların çalışmalarını aksatmakta ve onların daha yetkin birer akademisyen olmalarına ve profesyonel kariyerlerinde yükselmelerine engel teşkil edebilmektedir. Kadınların akademik hayatta daha verimli çalışabilmeleri ve bahsi geçen sorunlarla karşılaşmadan yükselebilmeleri için bu engellerin ortadan kaldırılmaları gerekmektedir. Bu nedenle çözüm önerileri bulabilmek için bir örneklendirme olarak Yıldız Teknik Üniversitesi Fen-Edebiyat Fakültesi, Elektrik Elektronik Fakültesi ve Makine Fakültesi’ndeki akademisyen kadınlarla elimizdeki bu çalıșma yapılmıștır. Bu çalıșmada farklı fakültelerden, sınırlı sayıda akademisyen kadınla yüz-yüze görüşülerek örnekleme metoduna dayalı veri analizi esas alınmıștır. Yapılan yüz-yüze görüșmelerde akademisyenlere sorulan sorular üç ana başlık altında toplanmıștır. Buna göre birinci bölümde; akademisyen kadınların iș hayatına yönelik sorular, ikinci bölümde aile hayatına ilișkin sorular bulunurken; üçüncü bölümde daha çok akademisyen kadınların ilgi ve alakaları, hobileri, kısaca boș vakitlerini nasıl değerlendirdikleri sorulmuștur. Bu soruların hazırlanmasındaki amaç; farklı disiplinlerde görev yapan akademisyen kadınların iş ve aile yaşamlarına ilişkin sorunlarını tespit ederek, bu sorunların giderilmesine yönelik önerileri sistematik bir şekilde dile getirmektir. Elde edilen bulgular, toplumsal cinsiyet rollere dayalı etkiler barındırmakta ve eğitim düzeyinden bağımsız cinsiyete dayalı ön kabullerin varlığına ișaret etmektedir. Bu doğrultuda hem söz konusu etkilerin hem de cinsiyete dayalı ön kabullerin göz önünde bulundurulmasıly kalıcı çözümler üretmek mümkün olacaktır.

Anahtar Kelimeler: Kadın, Akademi, Aile, Kariyer, Cinsiyet, Toplumsal cinsiyet, Ev hayatı, İş hayatı, Annelik, Çocuk bakımı, Evlilik, Akademide kadın, Eğitim.

\begin{abstract}
Academic life in today's Turkey brings with many problems to all its members regardless of their sex. However, personal problems in addition to sex or gender related problems affect women's studies directly, preventing them from becoming more competent academicians also excelling in their professional careers. In order for women to have a more productive academic life and advance in their careers without having
\end{abstract}

* Yrd. Doç. Dr., Yıldız Teknik Üniversitesi, Fen-Edebiyat Fakültesi, songuldk@yildiz.edu.tr 
to face aforementioned problems, these obstacles need to be eliminated. To this end we have conducted this study with women academicians as a sample, from Faculty of Arts and Sciences, Faculty of Electrical and Electronics Engineering and Faculty of Mechanical Engineering at Ylldız Technical University. The study is grounded on a sampling method of data analysis gathered from the face-to-face interviews conducted with limited number of academician women from different faculties. Through these faceto-face interviews academicians were asked questions under three main sections. Hereunder, the first section presents questions concerning their work life; the second section presents questions regarding their domestic life; and finally the third section presents questions regarding their interests, hobbies and how they spend their leisure time. The questions in these three sections were aimed at detecting the problems academician women from various disciplines have in their professional and domestic lives; and systematically offering possible solutions to these problems. The results gathered from the study indicate effects based on gender roles and implies the existence of sex-related prejudices independently of their level of education. In this respect, permanent solutions towards an improvement programme can only be found only by considering both these effects and gender related prejudices.

Keywords: Woman, Academia, Family, Career, Sex, Gender, Domestic Life, Work Life, Motherhood, Child Care, Marriage, Woman in Academia, Education.

\section{Giriş}

Her ne kadar bilimsel olarak birçok yeniliğin olduğu oldukça önemli keşiflerin yapıldığı bir çağda yaşıyor olsak da, akademik alanda çalışma yapan kadınlar gerek kariyerlerini ilerletme de gerekse bilimsel çalışmalarını gerçekleştirme de hala bazı zorluklarla karşılaşmaktadırlar. Yaşanan zorluklar nedeniyle kadınlar bilim dünyasında oldukça dar bir alanda iş görmekte ve çok az katkı sağlayabilmektedirler. ${ }^{1}$ Öte yandan kadınların akademik alanda yönetici olarak göreve gelmeleri hemen hemen mümkün olamamaktadır. Bir şekilde yönetici olarak görev alabilseler bile bu sayısı göz önünde bulundurulmayacak kadar azdır.

Bu çalışmada hedef kitle rahatlıkla anlaşılacağı üzere farklı disiplinlerde görev yapan akademisyen kadınlardır. Farklı disiplinlerde çalışma yapan akademisyen kadınların sorunları ise şu hususlar çerçevesinde ele alınmaktadır:

İlk olarak, farklı disiplinlerde görev yapan akademisyen kadınların akademik kariyerlerini sürdürmelerini zora sokan veya yavaşlamasına neden olan problemleri belirlemek amaçlanmıştır. Daha sonra, ev-içi alana ilişkin hayatları göz önünde bulundurularak, akademik hayattın aile yaşamlarını nasıl etkilendiğine ilişkin sorunlarını, bu sorunların giderilmesine ilişkin önerileri, hem kadınların bakış açıları ile ortaya koyabilmek, hem de sistematik bir biçimde dile getirmek amacı güdülmüştür.

1 Kadınların akademik alandaki çalışmalarında karşılaştıkları zorluklar, sadece Türkiye’de yaşayan akademisyenler için geçerli değildir. Aksine akademik alanda çalışan kadın sayısının erkek akademisyenlere göre az olması veya kadınların, akademik çalışma ile aile kurma arasında denge kurmak zorunda olmaları başka ülkelerdeki akademisyen kadınların da karşılaştıkları sorunlardır. Örneğin, İkinci Dünya Savaşı’ndan sonra kadınların birçok açıdan güçlü olduğu Almanyada bile benzer sorunlara rastlamak mümkündür. Bkz. PetraHofman: "WeiblicheArbeitswelten in der Wissenschaft, Frauen an der PreußischenAkademie der wissenschaftenzuberlin 1890-1945, transcriptVerlag, Bielefeld, 2011, StatistischesBundesamt (İstatistik Kurumu):"Auf dem wegzuGleichstellung? Bildung, arbeitundSoziales UnterschiedezwischenfrauenundMånnern”, StatistischesBundesamt, Wiesbaden, 2014. 
$\mathrm{Bu}$ çalışmayı yapmakta bizi motive eden en önemli husus, geçmişten günümüze kadın akademisyenlerin sayısının düzenli bir şekilde artması, fakat buna rağmen sorunları hakkında kafa yoran, fikir üreten çalışmaların neredeyse yok denecek kadar az olmasıdır. YÖK sisteminin erişimimize açtığ ilk yıl olan 1984 ile son yıl olan 2016 ve aradaki değişimi daha iyi gözlemleyebilmek adına, kabaca bunların ortası sayılabilecek 2001 yıllarının verileri ele alınmıştır. 1984, 2001 ve 2016 yıllarına ilişkin öğretim elemanı dağılım tablolarına baktığımızda, akademisyen kadın sayısının toplam akademisyen sayısına oranının düzenli şekilde arttığı açıkça görülmektedir. ${ }^{2}$

Tablo I. 1984 yılı Kadın Öğretim Elemanı Dağıımı Tablosu

\begin{tabular}{|l|l|l|l|}
\hline & Toplam & Kadın & $\%$ \\
\hline Profesör & 1.823 & 290 & 15,9 \\
\hline Doçent & 2.596 & 547 & 21 \\
\hline Yrd. Doç. Dr. & 2.407 & 560 & 23,2 \\
\hline Öğr. Gör. & 3.840 & 1.114 & 29 \\
\hline Okutman & 1.119 & 700 & 62,5 \\
\hline Uzman & 576 & 230 & 39,9 \\
\hline Arş. Gör. & 7.908 & 2.404 & 30,3 \\
\hline Türkiye geneli & 20.333 & 5.865 & 28,8 \\
\hline
\end{tabular}

Tablo 2. 200 I yılı Kadın Öğretim Elemanı Dağııımı Tablosu

\begin{tabular}{|l|l|l|l|}
\hline & Toplam & Kadın & $\%$ \\
\hline Profesör & 8.682 & 2.178 & 25 \\
\hline Doçent & 5.104 & 1.599 & 31,3 \\
\hline Yrd. Doç. Dr. & 10.189 & 3.029 & 29,7 \\
\hline Öğr. Gör. & 9.668 & 3.453 & 35,7 \\
\hline Okutman & 5.344 & 3.031 & 56,7 \\
\hline Uzman & 2.191 & 972 & 44,3 \\
\hline Arş. Gör. & 25.542 & 9.998 & 39,1 \\
\hline Türkiye geneli & 66.750 & 24.274 & 36,3 \\
\hline
\end{tabular}

Tablo 3. 2016 yılı Kadın Öğretim Elemanı Dağııımı Tablosu

\begin{tabular}{|l|l|l|l|}
\hline & Toplam & Kadın & $\%$ \\
\hline Profesör & 22.416 & 6.626 & 29,5 \\
\hline Doçent & 15.023 & 5.285 & 35,1 \\
\hline Yrd. Doç. Dr. & 35.301 & 14.214 & 40,2 \\
\hline Öğr. Gör. & 20.943 & 9.123 & 43,5 \\
\hline Okutman & 10.295 & 6.341 & 61,5 \\
\hline Uzman & 3.865 & 1.897 & 49 \\
\hline Arş. Gör. & 47.373 & 23.616 & 49,8 \\
\hline Türkiye geneli & 155.256 & 67.126 & 43,2 \\
\hline
\end{tabular}

2 Ylllara göre öğretim elemanı bilgilerine YÖK sistemindeki şu linkten ulaşmak mümkündür: https://istatistik.yok. gov.tr 
Tablolardan da anlaşılacağı üzere Türkiye genelinde kadın öğretim elemanı sayısı 32 yıl içinde yaklaşık olarak yüzde elli bir artış göstermiştir. Bu artış içerisinde özellikle yardımcı doçentler ve araştırma görevlilerinin sayısı, diğer unvanlardakine kıyasla daha fazladır.

Yukarıda da belirtildiği gibi tablolarda görülen bu artışa nazaran, kadınların akademik hayatlarındaki sorunlara ve bu sorunların iyileştirilmesine yönelik çözümler öneren veya üreten çalışmalar çok yetersiz kalmaktadır. Bu sebeple ele alınan bu çalışmanın, alandaki önemli bir boşluğu doldurması öngörülmektedir.

\section{Bilimsel Çalışma}

Metodik ve sistematik olarak bilimsel yapı ile düzenlenmiş bir çalışma akademik bir çalışma olarak belirlenebilir. Bilim insanı yaptığı araştırma ve keşifler sonucu bahsi geçen bilimsel yapıyı oluşturur. Aynı zamanda metodolojik çalışma, temelde ilgili disiplin çerçevesinde belirli konular için uygun yöntem belirlemeyi zorunlu kılar. Buna bağlı olarak öncelikle pratik ve teorik çalışma arasında ayrım yapılması gerekir. Teorik çalışmada esas olan, ileri sürülen görüş hakkında literatür geliştirmek veya bağlı olduğu literatür hakkında araştırma yapmaktır. Pratik çalışmada ise, araştırma nesnesi hakkında doğrudan ampirik çalışma gerçekleştirilerek veri elde edilir ve elde edilen veriler hakkında sistematik olarak belge düzenlenmesi yapılır.

Yukarıda dile getirilenler ışı̆̆ında söylenebilir ki; teorik ve pratik alanda yapılan bilimsel çalışmanın en temelinde metot ve bilimsel yaklaşım farklılığı vardır. Bu farklılık kimi zaman bu işi araştırmacı veya bir meslek olarak yürüten kişilerde de görmek mümkündür. Örneğin; eğitim bilimlerinde bilimsel çalışma yürüten bir kişi toplumsal düzlemde ve yine toplumsal gereklilikler çerçevesinde hareket ederken (Brezinka, 1971), kimya mühendisliğinde bilimsel çalışma yapan bir kişi kullandığı materyal açısından ihtiyaç ve gereklilikleri belirleyecektir. Esasında bilimsel yaklaşıma ve çalışma alanına göre ortaya çıkan farklılıkları şöyle sınıflandırmak mümkündür (Ulrich, 1982):

Maddi açıdan farklılık; bu farklılık bilimsel çalışma için kullanılan araç ve gereçler açısından ortaya çıkar.

Biyolojik açıdan farklılık: bilimsel çalışmanın kimin tarafından yürütüldüğü ile ortaya çıkan farklilik.

Kültürel açıdan farklılık; bilimsel çalışmanın nerede yürütüldüğü ve hangi görüşleri temele aldığı ile ilgili meydana gelen farklılıktır.

Bilimsel çalışma ile ilgili yapılan bu ayrım ve işaret edilen maddeler, bu bilimsel çalışmanın meslek olarak nasıl ortaya konulduğunu da doğrudan etkilemektedir. Lisansüstü eğitim alıyor olmak, muhakkak akademik ya da bilimsel çalışma yapılacağının garantisi değildir. Ancak bu türden bir yüksek eğitim almak, öğretim elemanı olarak görev yapabilmenin, ilk ve gerekli koşuludur. Dolayısıyla, akademisyen olarak görev alabilmelerinden önce, lisans ve lisansüstü eğitim alan öğrencilerin ne kadarını kadınların oluşturduğu, değerlendirme yapılabilmesi için başvurulması 
gereken verilere erişimi gerekli kılar. Bu bağlamda T.C. Aile ve Sosyal Politikalar Bakanlığı’na bağlı Kadının Statüsü ve Sorunları Genel Müdürlüğü biriminin Mayıs 2017 tarihli “Türkiyede Kadın” raporuna göre, 2015-2016 öğretim yılı sayıları göz önünde bulundurulduğunda üniversitede eğitimini sürdüren 6.689.185 öğrenciden \%45,8’i kadındır. Bununla birlikte bu oran, lisansüstü düzeyde lisans düzeyine yakın olmakla beraber, yüksek lisans programına devam eden öğrencilerin \%40,1’ını kadınlar oluşturmaktadır. Bir diğer lisansüstü programı olan doktora programına devam eden öğrencilerin ise \%41,4’ünü kadınlar oluşturmaktadır. Bu oranların bize, lisansüstü programlarda eğitim alan kadın sayısının, erkeklere nazaran daha az olmakla birlikte, yine de oldukça ciddi oranda katılımda bulunduklarını göstermektedir. Ayrıca, bu veriler ışığında, kadınların yüksek lisans ve doktoraya katılım oranları göz önünde bulundurulduğunda, bilimsel çalışmanın kadınlar tarafından meslek olarak algılandığı söylenebilir.

\section{Bir Meslek Olarak Bilimsel Çalışma}

Bilimsel çalışma günümüz şartlarında özellikle ya araştırma merkezlerinde ya da üniversitelerde yapılan çalışmalarla yürütülmektedir. Araştırma merkezlerinde yürütülen çalışmalardan farklı olarak üniversitelerde yürütülen çalışmalar; bir yandan farklı projelerin araştırılması ve geliştirilmesini sağlarken, diğer yandan alana ait öğrenci yetiştirerek katkı sağlamaktadır (Weber, 1995). Öte yandan üniversitede yapılan bilimsel çalışma ayrıca doğrudan kişinin mesleki durumunu da etkilemektedir. Bilim insanı yaptığı bilimsel çalışma ile bilim dünyasına katkıda bulunurken diğer yandan da akademik ilerleme sağlayarak kariyerini yükseltme ve akademik derece -Yardımcı Doçent, Doçent ve Profesör - almaktadır. Sonuç olarak üniversite de yapılan bilimsel çalışmanın mesleki açıdan üç yönü bulunmaktadır. Birinci olarak akademik çalışma salt bilimsel bir çalışmadır ve bu anlamda katkı sağlar. İkincisi, akademik çalışma öğrenci

yetiştirilmesini hedefler ve eğitim verir. Üçüncüsü ise, kişinin bilimsel kariyerini destekleyerek bireysel olarak ilerlemesini ve unvan almasını mümkün kılar.

Ayrıca yukarıda çalışma alanına ve yaklaşıma göre dile getirilen farklılıklar da göz önünde bulundurulduğunda, akademik çalışmanın çok yönlü düşülmesi gereken bir meslek olduğu vurgulamak yerinde olacaktır. Ancak, ele alınan bu çalışma yukarıda dile getirilen bu çok yönlülüğ̈ biyolojik farklılığı öne çıkararak kadın akademisyenler açısından ele almaktadır. Böylece akademik çalışma: bir yandan çok yönlülüğüyle analiz edilirken, diğer yandan sadece belirli bir kitle hedef alınarak sınırlandırma yapılmıştır. Böylece yapılan sınırlandırmaya uygun tespitlerde bulunmak ve gerektiğinde çözüm önerebilmek mümkün olmuştur.

\section{Akademi ve Kadın}

Yukarıda da belirtildiği üzere bu çalışma; Yıldız Teknik Üniversitesi Fen-Edebiyat Fakültesi, Elektrik Elektronik Fakültesi ve Makine Fakültesi'nden "Akademisyen Kadınlar" ile örneklendirilerek yapılmıştır. Bu amaçlı örneklendirme yukarıda adı geçen üç fakülteden toplam yüz (100) kadın akademisyen ile yüz-yüze yapılandırılmış soru formu uygulanarak elde 
edilmiştir. Örnek olarak yüz kadın akademisyen seçilmesinin nedeni, öncelikle detaylı bilgi elde etmek için sayının makul bir rakam içermesidir. Ayrıca veri toplamak için seçilen metot yüz yüze görüşmedir ve bu görüşmelerin yapılması zaman ve maliyet açısından zorlayıcı olabilmektedir. Bu nedenle yapılabilir, sınırlı sayıda görüşme planlayabilmek yüz (100) sayısının belirlenmesinde önemli rol oynamıştır.

Elde edilen verilerde akademisyen kadınların mesleklerini memnuniyetle yürüttükleri görülmüştür. Çalışma hayatı, kadına bir yandan ekonomik bağımsızlı̆̆ı verirken diğer yandan kadının toplumsal statüsünü destekleyerek yaşamdan tatmin olmayı sağlamaktadır. Ayrıca akademik çalışmada düzenli çalışma saatlerinin olması, hatta çalışma saatlerinin ihtiyaç dâhilinde farklı şekillerde düzenlenebilir olması, mesleki açıdan kadınları rahatlatmaktadır. Bu rahatlık daha çok kadınların çocuklarına ve eşlerine daha fazla vakit ayırmalarına imkân vermektedir. Hatta bu bakış açısına göre 45-65 yaş aralığındaki akademisyen kadınlar kendi dönemlerinde aile hayatına sahip olmanın ya da çocuk yapmanın akademik hayatta yükselmeye engel olacağını düşünür iken; bilhassa 25-40 yaş aralığındaki akademisyen kadınlar kariyerin aile yaşamına ve çocuk yapmaya engel olmadığ düşüncesine sahiptirler.

Akademisyenliğin zamansal ve mekânsal esnekliğe sahip bir kariyer olması, akademisyenliği tercih edilir bir meslek kılmaktadır. Tablo 1, 2 ve 3 de bu durumu destekler görünmektedir. Dünyada ve Türkiye'deki üniversite sayısındaki artışın, toplam akademisyen sayısını, dolayısıyla kadın akademisyen sayısını artırdığını göz ardı etmemek gerekir. Bunda hemen her ilde açılan yeni üniversiteler kadar, bilhassa 21. yüzyıl ile akademiye giren mesleki ve temel bilim alanlarındaki çeşitlilik ve yeniliklerin katkısı büyüktür. Ancak dikkat edildiğinde tablolardaki değişimin yalnızca akademisyen kadınların sayılarındaki bir artış olmadığı dikkat çekmektedir. Açıktır ki, yalnızca sayıda gerçekleşen bir artış, gerçek bir iyileşmeye işaret etmek için yeterli değildir. Yani, hem erkek hem de kadın sayısında gözlemlenen toplu bir artış, kadınların sayısındaki artışın etkisini azaltacaktır. Ancak, burada ele aldı̆̆ımız tablolar göstermektedir ki, akademisyen kadınların sayılarıyla birlikte yüzdeleri, yani oranları da artış göstermiştir. $\mathrm{O}$ halde, bu yüzdedeki değişime göre, kadınların sayısındaki artış, erkeklerinkine kıyasla daha büyüktür.

Bu çalışmanın ortaya koyduğu en önemli tespitlerden birisi, gerek sosyal bilimler alanında gerekse mühendislik alanında çok az sayıda kadının yönetici pozisyonda bulunduğudur. Yani genel olarak akademisyen kadınlar, akademik hayatlarına yönetici olarak yön verememektedirler. Oysa yapılan çalışmalar göstermiştir ki, kadın ve erkek yöneticilerin kabiliyetleri, tavır ve davranışları, algıda bulunan ve gerçeği yansıtmayan bir farklılığa işaret etmektedir. Kadın ve erkek yönetici arasında yapılan ayrıma ilişkin pek çok çalışma aslında yöneticilik pratikleri arasında bir fark olmadığını ortaya koymaktadır (Madeline, 1997).

Türkiyede akademisyenlerin toplam sayısına bakıldığında, kadınların \%43,5 ile dünya ortalamasının çok üzerinde olduğu gözlemlenmektedir. Ancak bu sayılara Profesör, Doçent, Yardımcı Doçent, Öğretim Görevlisi, Araştırma Görevlisi, Uzman, Çevirici ve Okutman kadrolarının tamamı dâhildir. Öyle ki, 2016 yılı YÖK sistemine kayıtlı öğretim elemanı 
istatistiklerine göre, profesörlerin \%29,5 kadın iken, kadınların akademide yönetici pozisyonda göreve katılımları ile ilgili verilere bakıldığında, Türkiyedeki rektör sayısının sadece \%9,03’ünü kadın rektörler oluşturmaktadır. Bu veriler, küçük ölçekli olarak gerçekleştirilen bu çalışmada öne sürmüş olduğumuz gibi bize göstermektedir ki çok az sayıda kadının akademide yönetici pozisyonunda bulunduğu savını desteklemektedir (Anon, 2017).

Bu sayıların sağlıklı bir şekilde değerlendirilebilmesi için Türkiyede her meslekte kadınların yönetici pozisyonunda temsil düzeyi de göz önünde bulundurmak gerekmektedir. Zira eğer kadınlar diğer mesleklerdeki yönetici pozisyonlarda da rektörlükteki kadar az ya da ona yakın bir yüzde ile katılımda bulunuyorlarsa, bu sorunun yalnız akademiye has bir durum olmadığı; dahası genel bir sorun olduğu sonucu çıkarsanabilir. Bu amaç doğrultusunda, “Türkiye'de Kadın 2017” raporunun sunduğu verilere göre, toplumsal normlar açısından "erkek mesleği” olarak kabul gören meslek gruplarından emniyet amirlerinin \%8,1'i ve baş komiserlerin \%7,4'ü kadındır. Bir diğer erkek egemen alan olan bürokraside üst düzey yöneticiliklerin \%10,89'unu kadınlar oluştururken, yine bu görevlerdeki özel dağılımlarına bakıldığında örneğin, 1 kadın Müsteşar yardımcısı, 6 Genel Müdür, 34 Genel Müdür Yardımcısı, 369 Daire Başkanının görev yaptığı gözlenmiştir. Bununla birlikte yine bir eğitim alanı olan ilk ve orta öğretim düzeyindeki yönetici pozisyonlarında görev yapan kadın sayılarına bakıldığında ise, İl Millî Eğitim Müdürlerinin \%1,23'ü, İlçe Millî Eğitim Müdürlerinin \%0,7’si, okul müdürlerinin \%7,91’i kadın olduğu görülmektedir (Anon, 2017).

Yukarıdaki veriler ışı̆̆ı̆nda bahsedildiği üzere, farklı meslek alanlarında da kadınların yönetici pozisyonda görev alması oldukça zordur. Bu durumun en önemli sebebi, kadınların aile yaşamı içinde üstlenmek zorunda oldukları görevleridir. Buradaki en büyük etken ise, çocuk sahibi kadınların biyolojik zorunluluk nedeniyle işlerinden bir süreliğine de olsa uzaklaşmak mecburiyetinde olmalarıdır. Bu kesinti ise kaçınılmaz olarak kadınların akademik kariyerlerini erkeklere nazaran daha yavaş yürütmeleri ve bir süreliğine de olsa kariyerlerinin kesintiye uğraması sonucunu doğurmaktadır. Bu durum, annenin çocuğuyla daha çok ve daha rahat vakit geçirebilmesine imkân vermekle birlikte kişinin kariyerinde oluşabilecek boşluklara mahal vermekte, annenin akademik kariyerini bir bakıma ya tamamen bırakmasına en iyi ihtimalle de ertelemesine sebep olmaktadır. Annenin söz konusu fedakârlığı doğal bir zorunluluk gibi görünse de sanayi öncesi toplumlar ve sanayi toplumlar karşılaştırıldığında bu durumun aslında büyük oranda iş çevresindeki faktörlerle şekillenmekte olduğu gözlemlenebilir.

Ayrıca bir diğer önemli tespit de hem sosyal bilimler alanında hem de mühendislik alanında kadınların bir şekilde cinsiyet ayrımcılığına maruz kalıyor olmalarıdır. Kadın akademisyenler iş ve aile arasında denge kurma çabası içinde koşuştururken, erkek akademisyenler çoğunlukla ortak çalışma alanlarında örneğin, proje, bilirkişi kurulları, akademik kurullar için yine erkek meslektaşlarını tercih etmektedirler. Buna göre ise, farklı disiplinlerde farklı çalışma alanlarında akademisyen kadınlara karşı ortak tutum sergilendiği görülmekte, akademik yönetime katılım ve bilim alanında cinsiyet ayrımcılığı olduğu ifade edilmektedir (Kandiyoti, 1997). ${ }^{3}$ Bunun

3 Her ne kadar kamu alanında doğrudan cinsiyet farkı olduğu söylenemese de bazı meslekler için bu söz konusudur. 
yanı sıra kadın ve erkeklerin ev ve iş hayatında aldıkları ödevler üzerine yapılan çalışmalarda hemen her toplumda her iki cinsiyete de atfedilen roller olduğu ve bu rollerin temelde cinsiyet rolleri arasındaki ayrıma dayandığ (Spence, Helmreich, 1972) göz önüne alındığında ülkemizde akademik hayat içerisinde yer alan kadınların da bu ayrıma tabi oldukları açıktır. Bu sorunu aşmak için akademisyen kadınların herhangi bir çabasının olup olmadığı sorusu ise oldukça bireysel düzlemde cevap bulmaktadır. Akademisyen kadınlar kendi bireysel çabaları ile kariyerlerindeki engelleri aşma yoluna gitmekte bunun içinde daha çok eşlerinden destek aldıklarını belirtmektedirler.

Araştırmanın üçüncü bölümünde akademisyen kadınların sadece iş ve aile hayatı değil, kendi bireysel alanlarındaki aktiviteler irdelenmiştir. Böylece kadınların iş ve aile dışında kendilerini nasıl tanımladıkları, iş ve aile dışındaki ilgi ve alakanın onların yaşamını nasıl etkilediği araştırılmıştır. Ancak görüldüğü üzere akademisyen kadınlar boş vakitlerini herhangi bir ilgi ve alakaya yönlendirmek yerine daha çok arkadaşlarına, ailelerine ayırmaktadırlar.

Yukarıda, yapılan çalışmanın verileri genel olarak değerlendirilmiştir. Elde edilen bu veriler, aşağıdaki sorulara verilen yanıtlara dayanarak düzenlenmiştir. Buna göre daha önce de belirtildiği gibi Fen-Edebiyat Fakültesi'nden sözel (38) ve sayısal (35) alanlardan, Elektrik Elektronik Fakültesi (13) ve Makine Fakültesi’nden (14) olmak üzere yüz akademisyen kadın ile yüz yüze yapılan görüşmeler sonucunda şu sonuçlara ulaşılmıştır.

Yüz yüze yapılan görüşmeler, 3 ana başl1kta toplanmıştır.

\section{Profil ve Akademik Alan}

Profil şu başlıklarla belirlenmiştir: yaş, görev yaptığı bölüm, unvanı, idari görev, medeni hal, çocuk, aylık gelir, eş mesleği. Bu maddelere cevaben verilen bilgiler aracılığıyla araştırmaya katılan akademisyen kadınların profesyonel, ekonomik ve kişisel hayatları hakkında bir profil çıkarılması amaçlanmıştır. Böylece ilerleyen bölümlerdeki sorulara verilen yanıtlar daha sağlıklı değerlendirilirken bir taraftan da belli profil özellikleri ile benzerlik taşıyan gruplar arasında karşılaştırma yapmak mümkün olmuştur. Örneğin yaş ve unvan açısından gruplandırıldı̆̆ında ayni gruba dâhil olmayan kadınların evlilik hayatı ve çocuk sahibi olmaya ilişkin verdikleri cevaplarda da farklılıklar görülmüştür. Kısaca profil ve akademik alana ilişskin veriler diğer başlıklar içerisinde ilgili kısımlarda verilmiştir.

Çalışmada akademisyen kadınların profilleriyle ilgili birtakım bilgiler içeren tablolar aşağıdaki gibidir: 
Tablo 4. Fakültelerine Göre Medeni Durumları

\begin{tabular}{|l|l|l|l|l|}
\hline & Makine Fakültesi & $\begin{array}{l}\text { Elektrik-Elektronik } \\
\text { Fakültesi }\end{array}$ & $\begin{array}{l}\text { Fen-Edebiyat } \\
\text { Fakültesi (Sayısal) }\end{array}$ & $\begin{array}{l}\text { Fen-Edebiyat } \\
\text { Fakültesi (Sözel) }\end{array}$ \\
\hline Prof. Dr. & 1E 1B & 1E 1B & 5E 3B & 6E 1B \\
\hline Doç. Dr. & 3E 1B & 1E & 3E 5B & 3E 1B \\
\hline Yrd. Doç. Dr. & 4E & 2E & 6E 2B & 5E 1B \\
\hline Arș. Gör. Dr. & 1E & 1B & 3E 1B & 2B \\
\hline Arš. Gör. & 3E & 3E 4B & 2E 4B & 7E 8B \\
\hline Öğr. Gör. & & & 1E & 2E 2B \\
\hline
\end{tabular}

Tablo 5. Fakültelerine Göre Çocuk Sahibi Olma Durumu

\begin{tabular}{|l|l|l|l|l|l|l|l|l|}
\hline & \multicolumn{2}{|l|}{ Makine Fakültesi } & \multicolumn{2}{l|}{$\begin{array}{l}\text { Elektrik-Elektronik } \\
\text { Fakültesi }\end{array}$} & \multicolumn{2}{l}{$\begin{array}{l}\text { Fen-Edebiyat Fakültesi } \\
\text { (Sayısal) }\end{array}$} & $\begin{array}{l}\text { Fen-Edebiyat Fakültesi } \\
\text { (Sözel) }\end{array}$ \\
& $\begin{array}{l}\text { Çocuğu } \\
\text { var }\end{array}$ & $\begin{array}{l}\text { Çocuğu } \\
\text { yok }\end{array}$ & $\begin{array}{l}\text { Çocuğu } \\
\text { var }\end{array}$ & $\begin{array}{l}\text { Çocuğu } \\
\text { yok }\end{array}$ & $\begin{array}{l}\text { Çocuğu } \\
\text { var }\end{array}$ & $\begin{array}{l}\text { Çocuğu } \\
\text { yok }\end{array}$ & $\begin{array}{l}\text { Çocuğu } \\
\text { var }\end{array}$ & $\begin{array}{l}\text { Çocuğu } \\
\text { yok }\end{array}$ \\
\hline Prof. Dr. & 1 & 1 & 1 & 1 & 5 & 3 & 7 & \\
\hline Doç. Dr. & 4 & & 1 & & 4 & 4 & 3 & 1 \\
\hline Yrd. Doç. Dr. & 3 & 1 & 1 & 1 & 6 & 2 & 3 & 3 \\
\hline Arș. Gör. Dr. & 1 & & & 1 & 4 & & & 2 \\
\hline Arş. Gör. & 1 & 2 & 1 & 6 & 1 & 5 & 2 & 13 \\
\hline Öğgr. Gör. & & & & & 1 & & 2 & 2 \\
\hline
\end{tabular}

Tablo 6. Fakültelerine Göre İdari Görev Deneyimine İlişkin Durum

\begin{tabular}{|l|l|l|l|l|l|l|l|l|}
\hline & Makine Fakültesi & \multicolumn{2}{l|}{$\begin{array}{l}\text { Elektrik-Elektronik } \\
\text { Fakültesi }\end{array}$} & \multicolumn{2}{l|}{$\begin{array}{l}\text { Fen-Edebiyat Fakültesi } \\
\text { (Sayıal) }\end{array}$} & $\begin{array}{l}\text { Fen-Edebiyat Fakültesi } \\
\text { (Sözel) }\end{array}$ \\
\hline & $\begin{array}{l}\text { İdari görev } \\
\text { deneyimi } \\
\text { var }\end{array}$ & $\begin{array}{l}\text { İdari görev } \\
\text { deneyimi } \\
\text { yok }\end{array}$ & $\begin{array}{l}\text { Idari görev } \\
\text { deneyimi } \\
\text { var }\end{array}$ & $\begin{array}{l}\text { Idari görev } \\
\text { deneyimi } \\
\text { yok }\end{array}$ & $\begin{array}{l}\text { İdari görev } \\
\text { deneyimi } \\
\text { var }\end{array}$ & $\begin{array}{l}\text { Idari görev } \\
\text { deneyimi } \\
\text { yok }\end{array}$ & $\begin{array}{l}\text { Idari görev } \\
\text { deneyimi } \\
\text { var }\end{array}$ & $\begin{array}{l}\text { İdari görev } \\
\text { deneyimi } \\
\text { yok }\end{array}$ \\
\hline Prof. Dr. & & 2 & 1 & 1 & 2 & 6 & 5 & 2 \\
\hline Doç. Dr. & 1 & 3 & & 1 & & 8 & 1 & 3 \\
\hline Yrd. Doç. Dr. & & 4 & 1 & 1 & & 8 & 4 & 2 \\
\hline Arş. Gör. Dr. & & 1 & & 1 & 1 & 3 & 1 & 1 \\
\hline Arş. Gör. & & 3 & & 7 & & 6 & 2 & 13 \\
\hline Öğr. Gör. & & & & & & 1 & 1 & 3 \\
\hline
\end{tabular}

Yukarıda aktarılan tablolarda görüldüğü gibi Yıldız Teknik Üniversitesi’nde çalışan akademisyen kadınların, idari görevlerde çok az yer almaktadır; ve Üniversitede karar merciinde çok az söz sahibi olmaktadır. Bu bizim kadınların

\section{İş Hayatı}

İş hayatı toplam 6 soruyla irdelenmiştir. Söz konusu sorular, tek tek incelendiğinde aşağıdaki tabloyla karşılaşılmaktadır. Buna göre sorulara verilen cevapların değerlendirilmesi şöyledir: 
Birinci adım olarak doğrudan akademik hayata katılımda bulunup bulunulmadığı irdelendi. $\mathrm{Bu}$ amaç doğrultusunda çalışma kapsamında görüşülen akademisyen kadınlara "Mezun olur olmaz $\mathrm{m}$ akademisyen oldunuz? Yoksa akademik hayata ara verdiniz mi? Akademisyenliğin dişında sektör deneyiminiz var mı?” sorusu yöneltildi.

Yukarıdaki soruya verilen cevaba göre Fen Bilimleri ve Mühendislik alanlarında akademik çalışma yapan kadınlar -birkaç istisnai örnek dışında - çok uzun süreli olmamakla birlikte sektör deneyimine sahip olmuştur. Ancak Sosyal Bilimler alanlarında da Fen Bilimleri ve Mühendislik alanlarına kıyasla daha kısa süreli bir sektör deneyiminden söz edilebilmektedir. Örneğin Fen Bilimleri ve Mühendislik alanlarında çalışan akademisyen kadınların sektör deneyimleri 3 yıl ile 8 yıl arasında değişiklik gösterirken Sosyal Bilimler alanında çalışan akademisyen kadınların geçmiş sektör deneyimleri, 6 ay ile 1 yıl arasında seyretmektedir.

Arada çok büyük bir uçurum bulunmamakla birlikte göz ardı edilmemesi gereken bir dağılım farkı gözlemlenmektedir. Buna göre Fen Bilimleri ve Mühendislik alanlarında akademik hayattan önceki sektör deneyimi, Sosyal Bilimler alanlarına nazaran daha fazladır. Fakat, gerek zamanı planlamaktaki gerekse mekânsal getirileri açısından akademik hayatın avantajlarının akademiyi herhangi başka bir kuruma göre her iki alan için de daha tercih edilir kıldığı vurgulanmıştır.

Akademisyenliğin kadınlar tarafından zamansal ve mekânsal avantajları dolayısıyla daima tercih edilir bir meslek olması, son yıllardaki nicel verilerle de desteklenmektedir. Örneğin, 1984, 2001 ve 2016 yıllarına ait akademisyen sayı ve oranlarının verildiği Tablo 1, 2 ve 3 incelendiğinde kadın akademisyenlerin hem sayılarının hem de toplam sayıya nispetle yüzdelerinin düzenli bir şekilde arttığı açıktır. Bu da kadınlar tarafından profesyonel bir kariyer olarak tercih edildiği tezimizi güçlendirmektedir.

\section{Akademik Hedef ve Beklentiler}

Çalışmamız kapsamında bir diğer önemli husus da akademisyen kadınların profesyonel hayatlarıyla alakalı hedef ve beklentilerinin irdelenmesidir. Buna ilişkin öncelikle şu soruya yer verilmiştir: "Akademisyenliğe başladığınızda akademisyenliğe yönelik amaçlarınız var mıydı? Bu amaçlarınızı gerçekleştirebildiniz mi?”

Burada dile getirilen soruya verilen cevaplar, çok çeşitlilik arz etmektedir. Öyle ki herhangi bir alan farkı gözetmeksizin Fen-Edebiyat Fakültesi, Elektrik Elektronik Fakültesi ve Makine Fakültesi'nde çalışan ve anketimize katılan akademisyen kadınlar yaşamdan beklentilerine göre farklı cevaplar vermişlerdir. Örneğin kimisi o zamana kadar yaptığ 1 yetersiz görerek amaçlarını henüz gerçekleștiremediğini ifade ederken kimisi de amaçlarını kısmen gerçekleștirdiğini belirtmiştir. Bu durum da bize göstermektedir ki akademisyen kadınların kendilerinden beklentileri yine kendileri tarafından belirlenmektedir. Ve bu öznel ölçütler dolayısıyla da akademisyen kadınların amaçlarını gerçekleştirip gerçekleştiremedikleri hususunda somut bir yargıya ulaşmak mümkün görünmemektedir. 
Akademik çalışmada araştırma yapmak ve bu doğrultuda akademik bir ürün ortaya koymak akademik ilerleme ve unvan açısından bir gerekliliktir. Bu nedenle görüşmelerimiz kapsamında akademisyen kadınlara "Akademisyen olarak araştırma ağırlıklı mı yoksa eğitim ağırlıklı mı çalışıyorsunuz?” sorusu sorularak akademisyen kadınların çalışmalarını nasıl yürüttüklerinin bilgisi amaçlanmıştır.

Üniversitedeki sistem, sadece belirli konuda bilimsel araştırmaya yönelik değil, aynı zamanda bilimsel çalışmanın nasıl yapılacağına ilişkin eğitim vermeyi de amaçlar. Bu nedenle üniversitede çalışan akademisyen aynı zamanda bilimsel çalışmanın ne olduğunu, yöntemini aktarabilecek yeterliliğe sahip olmalıdır. Dolayısıyla araştırmacı kimliğinin yanı sıra eğitimci yönünü her zaman en etkili şekilde ortaya koyma çabası içerisindedir.

Bu soru çerçevesinde verilen cevaplara bakıldığında; Fen Bilimleri ve Mühendislik alanlarında araştırma ağırlıklı çalışanlar sayıca fazlayken Sosyal Bilimler alanında çalışanların eğitim ağırlıklı olarak işlerini yürüttükleri görülmektedir. Bununla birlikte gerek Fen Bilimleri ve Mühendislik alanlarında gerekse Sosyal Bilimler alanında çalışan akademisyen, aynı zamanda hem araştırmacı hem de eğitimci olmak zorundadır. Bu nedenle akademisyenlerin hangi alandan olurlarsa olsunlar salt eğitimci yahut salt araştırmacı olmaları beklenemez. Öncelikle bilim kadını oldukları unutulmamalıdır (Özdemir ve Tanyıldız, 2012). Ayrıca Sosyal Bilimler alanında ele alınan konuların gerek öğrencilerle çalıșılan tezler, gerekse bireysel ya da grup olarak ele alınan meseleler, projelendirilmeye her zaman müsait olamamaktadır. Bu nedenle özellikle Sosyal Bilimler alanında çalışan akademisyenlerin proje sayılarının Fen Bilimleri ve Mühendislik alanlarında çalışanlara göre daha az olması anlaşılır bir durumdur. Bu soruya verilen cevaplar yukarıda zikredilen durum çerçevesinde değerlendirilmiştir.

\section{Kadın Olmak ve Cinsiyete Dayalı Ayrımcılık}

Toplumun farklı alanlarında cinsiyete dayalı olarak kadına yönelik yapılan gerek pozitif gerekse negatif ayrımcılık akademik hayatta da kendini göstermektedir. Bu nedenle öncelik şu soruya verilmiştir: "Grup olarak yapılan akademik projelerde gözlemlediğiniz kadarıyla proje elemanlarının seçiminde cinsiyetçi bir ayrım fark ettiniz mi? Sizin kadın olduğunuz için kabul edilmediğinizi düşündügünüz bir proje oldu mu?”

Bu soruya verilen cevaplar doğrultusunda görülmektedir ki kadınlarla ilgili her iki alanda da kadınlara karşı ayrımcılık açık seçik şekilde görülmektedir. Araştırmada dikkat çeken bir diğer önemli unsur da Fen Bilimleri ve Mühendislik alanlarındaki Profesör ve Doçent akademisyen kadınların dahi cinsiyet ayrımcılığına maruz kaldığı gözlemlenmektedir.

Bununla birlikte bu konu ile ilgili şu meseleler öne sürülmektedir: Örneğin bir kadının hamilelik dönemi ve sonrasında akademik hayattan uzak kalması, onun bir projede gerek araştırmacı, ancak bilhassa yürütücü olarak görev almasını zorlaştırmaktadır. Hatta yüz-yüze anketimize katılan akademisyen kadınlardan biri, hamileliğinin sonlarına doğru "doğum iznine ayrılacağım 
için projede yer alamadım” derken, erkek bir meslektaşının hem doğum hem de annelik gibi görevlerden muaf olduğu için tercih edildiğini belirtmektedir. Bu da göstermektedir ki hamile bir kadının akademik hayattan bir süre uzak kalması, erkek meslektaşına göre onu birçok açıdan fırsat eşitsizliğine maruz bırakmaktadır. Herhangi bir kadro ilanına başvurması geciktiği gibi öğrenciyle iletişimi kesintiye uğramakta, çalıştı̆̆ 1 akademik birimde idari görev üstlenmesi de imkânsızlaşmaktadır. Ayrıca bahsi geçen fırsat eşitsizliği ve akademik yükselmede gecikme hali, sadece hamilelik sürecinde değil, hamilelik sonrasında da çocuğu belli bir yaşa gelene kadar annenin akademik kariyerinin gelişimi olumsuz yönde etkilemeye devam etmektedir. Bu nedenle, akademisyen kadınların sayısı daha çok Yardımcı Doçentlik unvanında yoğunlaşmakta ve daha yüksek unvanı alabilmeleri için gerekli koşulları yerine getirmeleri gecikmektedir. Bunun yanı sıra doktora çalışmasının tamamlanması sonrasında genellikle alınan ilk unvan olması nedeniyle de hem Yardımcı Doçentlik unvanına sahip akademisyen kadınların sayısı ve toplam akademisyen sayısına oranı, hem de Yardımcı Doçent akademisyenler tüm akademisyenlere oranı Tablo 1, 2 ve 3'te incelenebilir.

Bütün bunların yanı sıra ilginçtir ki mesleki kariyerinde ilerlemiş, daha yüksek unvana sahip akademisyen bir kadın yürüteceği projede birlikte çalışacağı meslektaşlarının erkek olmasını daha çok tercih etmektedir. Yukarıda dile getirilen akademisyen kadının bir süre akademik hayattan uzak kalması sorununun kendi hemcinsleri tarafından da karşı çıkılması gereken bir durum olması beklenirdi. Oysa akademisyen kadınların büyük kısmı hali hazırda fırsat eşitsizliği içinde bulunan hemcinslerine karşı bu firsat eşitsizliğini besleyecek şekilde bir tutum geliştirdiği gözlenmektedir (Benhabib, Butler, Cornell, Fraser, 2008). Bu ise başarılı veya başarılı olmayı isteyen kadınların erkekler gibi karakteristik bir tavır içinde olduğunu göstermektedir (Bora, 2002; Schein, 1975).

"Katıldığınız akademik bir ortamda kadın olduğunuz için size ayrıcalıklı davranıldığını hissettiniz mi? Bu durumun olumlu mu olumsuz mu olduğunu düşündünüz?”

Akademisyen kadınlara karşı ayrıcalıklı davranış, birçok açıdan ortaya çıkmaktadır. Özellikle Fen Bilimleri ve Mühendislik alanındaki akademisyen kadınlar, kendilerine karşı ayrıcalıklı tutum ve davranışlarda bulunulduğunu vurgulamışlardır. Örneğin, özellikle toplumsal normlar tarafından erkek mesleği olarak belirlenen çalışma alanlarında veya erkeklerin ağırlıklı olarak çalıştığı bölümlerde bir kadının yaptığı işin üstesinden gelip gelemeyeceği sorgulanıp kendini ispatlaması beklenirken erkek için böylesi bir durum söz konusu değildir. Ayrıca bahsi geçen kadına karşı ayrımcı tutum, yalnızca meslektaşlar arasında değil, akademisyenin öğrenci ile kurduğu ilişkide bile gözlemlenebilir bir hale gelmektedir. Erkek öğrencilerin ağırlıklı olduğu kimi bölümlerde kadın hocalar, zaman zaman bazı olumsuz durumlarla karşı karşıya kaldıklarını ifade etmektedirler. Örneğin, erkek öğrenciler erkek hocalara karşı davranışlarında daha çekingen ve saygılı bir tutum sergilerken aynı öğrencilerin kadın hocalarına karşı benzer şekilde davranmadıkları gözlemlenmektedir. Hatta kadın hocalar, erkek öğrencilerinin onlara saygılı davranmaları için özel bir çaba sarf ettiklerini dile getirmişlerdir. Böyle bir durum cinsiyetçi 
bakış açısının ve buna bağlı geliştirilen tutum ve davranışların çok genç yaşlarda ortaya çıktığını da ayrıca pekiştirmektedir (Dayığlu ve Kasnakoğlu, 1997; Dökmen, 2016; Butler, 2008).

Kadınlara karşı -bir kadın akademisyenin tabiriyle - "kibarlık kisvesi altında" gösterilen tutumlar ise birbirinden oldukça farklı iki bakış açısı tarafından değerlendirilmektedir. Kimi kadın akademisyenlere göre kibarlık adı altında gösterilen tutum pozitif ayrımcılığı pekiştirmektedir. Onlara göre kadın oldukları için işlerinin kolaylaştırılması, onlara öncelikli davranılması, özel muamele gösterilmesi, kısaca bir erkeğin bir başka erkeğe davrandığından daha farklı şekilde davranılması -kadının ağır malzemelerinin taşınması, resepsiyonlarda ya da bilimsel toplantılarda öne çıkarılmaları gibi - rahatsız edici değil aksine pozitif ayrımcılığı pekiştirici bir tutumdur. Söz konusu tutum ise bu kadınlar tarafından adeta cinsiyetlerinin gerektirdiği doğal bir hak gibi algılanmaktadır. Buna karşın kimi kadın akademisyenler ise erkekler tarafından kibarlık adı altında gösterilen tutumu kendilerine karşı yapılmış olumsuz bir hareket olarak algılamaktadırlar. Kadınların öne çıkarılmaları, hatta onların yerine eşyalarının taşınması, sanki ortada herhangi bir eşitsizlik varmışçasına bunun vurgulanması, kesinlikle kabul edilir bir tutum değildir. Bu karşı çıkışın sebebi ise erkeklerin bu durumu yeri geldiğinde kadınlar üzerinde bir tür egemenlik kurma ve güç mücadelesine dönüşebilme ihtimali dolayısıyladır. Kadınların böyle bir ihtimali göz önünde bulundurması, toplum tarafından öğretilmiş kültürel cinsiyet rolleri nedeniyledir (Kantor, Jarvis, Cloke, 2015). Bu ve benzeri tutumlar, toplumda kemikleşmiş mevcut rollerin akademik arenada da kendini bu şekilde göstermesine çok iyi bir örnek teşkil etmektedir.

Daha önce belirtildiği gibi akademik ilerleme açısından araştırma yapmak ve bu konuda bir ürün vermek ne kadar öncelikli bir husus ise, alanındaki ulusal ve uluslararası toplantılara dahil olmak da bir o kadar önceliklidir. Bu nedenle akademisyen kadınların ev-içi hayatlarının bu tür toplantılara katılımını nasıl etkilediği veya nasıl etkileyeceği şu soruyla ele alınmıştır: "Evli ya da çocuklu olmanız yurt dışı ya da şehir dışında gerçekleşecek akademik faaliyetlere katılmanızı ne yönde etkiliyor (ya da evli olsanız etkiler miydi, etkilerse nasıl etkilerdi)?”

Akademik hayat, ev-içi hayatın seyri, nasıl şekillendiği, hangi değişkenleri barındırdığ 1 ve bu değişkenlerin birbirini nasıl etkilediği ile doğrudan ilişkilidir. Öyle ki, meslekle ilgili değişkenler işin aileye müdahalesi ile daha alakalı iken, aileyle ilgili değişkenler, ailenin işüzerindeki müdahalesi üzerinde daha büyük etkiye sahiptir (Frone, Russell, Cooper, 1992). Yukarıda zikredilen soru ve bu soruya verilen cevaplar, sözü edilen ilişkiyi oldukça iyi ortaya koyacak şekildedir. Öyle ki farklı yaş ve akademik tecrübede kadınların verdikleri cevaplar, hayli verimli tespitlerin elde edilmesine vesile olmuştur. Henüz akademik kariyerinin başında, günlük hayatı nispeten daha değişken bir yapıda olan akademisyen kadınlar, ev-içi hayatın akademik hayatlarını çok fazla kısıtlamadığını ifade etmektedirler. Bunun aksine uzun süredir akademik hayatın içerisinde yer alan ve dönem itibari ile daha geleneksel bir kültürün içerisinde yetişmiş olan akademisyen kadınlar ise eviçi hayatlarının akademik hayatlarını olumsuz yönde etkilediğini belirtmişlerdir. Geleneksel kültürün etkisinde kalarak daha kısıtlayıcı bir yapı içerisinde olan aile ilişkileri, öğrenilmiş kültürel cinsel kimlik ve buna dayalı ayrımcılık, bu kadınların ev-içi hayatlarının akademik 
hayatlarındaki özgürlüklerini kısıtladığı hakkındaki kanaatlerini pekiştirici etkenlerdir. Öte yandan, kendilerini bu denli kısıtlanmış hissetmeyen akademisyen kadınlar ise kültürel cinsel kimliğin baskısına daha az maruz kalarak ve bu baskıyı akademik hayatlarına daha az yansıtarak hareket alanlarını genişletme imkânına sahip olmuşlardır.

Yukarıda tasvir edilen durum, çocuk sahibi olmak söz konusu olduğunda daha belirgin hatlarla ortaya çıkmaktadır. Akademik hayata yeni atılmış, genç akademisyen kadınlar için çocuk sahibi olmak, daha ileri yaşlardaki akademisyen kadınlara nazaran akademik hayatı kısıtlayıcı bir etken değildir. Annelik, özellikle yurtdışı ya da şehir dışında yer alan bilimsel bir toplantıya katılmak için engelleyici bir unsur olarak görülmemektedir. Oysa ileri yaşlardaki akademisyenler, anneliği daha bağlayıcı bir unsur olarak değerlendirmektedirler. Örneğin, çocuk sahibi olan akademisyen kadınlarla yapılan görüşmeler esnasında "yirmi yıl boyunca yurtdışı ya da şehir dışında gerçekleşen hiçbir bilimsel toplantıya katılamadım’ diyerek içinde bulundukları durumu ifade etmişlerdir. Doç. Dr. Özlem Belkıs`ın Dokuz Eylül Üniversitesi1nde anneliğin akademik kariyer üzerine yaptığı araştırma da yukarıda dile getirilen benzer bulgulara rastlamak mümkündür. Hatta kariyer gelişiminde, doktora sonrası akademik yükselmenin oransal düşüşünün nedenlerinden birinin anneliğin getirdiği toplumsal cinsiyet eşitsizliğine dayandığı belirtilmektedir (Belkıs, 2016).

Bütün bunların dışında evli ya da çocuklu olmayan akademisyen kadınlar, varsayımsal olarak evli ya da çocuklu oldukları takdirde bunun akademik hayatlarına nasıl yansıyacağ yöneltildiğinde, cevapları daha çok şu yönde olmuştur: onlara göre seçtikleri eş, eşlerinin bakış açısı ve buna bağlı geliştirdikleri tavır ve tutumlara bağlı olarak olumlu ya da olumsuz sonuçlar doğurabileceğini belirtmişlerdir. Buna göre henüz evlenmemiş akademisyen kadınların şehir dışı ya da yurtdışında gerçekleşen bilimsel toplantılara katılım durumunu eşlerinin mesleği belirleyecektir. Anlaşılacağı üzere, akademisyen kadınların gelecekte yaşayacağı olası bir evlilik hayatı özellikle çocuk hakkında bireysel düzenleme yapmaları ya da bu konuda bir öngörüde bulunmaları mümkün değildir. Kadınların bakış açısına göre erkeklerin mesleki hayatlarının, onların akademik hayatlarını planlamalarında önemli bir rol oynadığı anlayışı hâkimdir.

\section{Ev-içi Hayat}

Akademisyen kadınlar hakkında, icra ettikleri meslekleri nedeniyle çoğu zaman ya hiç evlenmedikleri ya da evliliği ileri yaşlara erteledikleri, evlenseler bile çocuk sahibi olmadıkları, çocuk sahibi olsalar bile tek çocukla sınırlandığı gibi kanaatler bulunmaktadır. Bu hususu aydınlatmak üzere aşağıdaki sorular yöneltilmiştir.

"Akademik hayatınızı biçimlendirmeniz (eğer vardıysa) evlilik ya da çocuk planlarınızı geciktirmenize sebep oldu mu?"

Bu soruya verilen yanıtlarda alandan daha çok, akademik unvan ayrımı göze çarpmaktadır. Akademik unvanı daha yüksek ya da daha uzun soluklu akademik geçmişi olan kadınlarda özel hayatlarında aile kurma veya çocuk sahibi olma planlarının etkilendiği gözlemlenmektedir. 
Özellikle "Önce akademik hayatıma yön vermek istedim”, "Doktora çalışmamı tamamlamadan çocuk yapmadım.”, Doktora çalışması sonrasında ancak tek çocuk yapabildim, çükü ikinci çocuk için geçti” gibi cevaplar verilmiştir.

Ayrıca yapılan çalışma ortaya koymaktadır ki, günlük yaşamdaki değişim, kadının toplumsal ve profesyonel hayattaki konumu, daha önce bahsi geçen jenerasyon farklılığının başlıca sorumlusudur.

Öte yandan alınan cevaplar doğrultusunda akademisyen kadınların çocuk sahibi olmayı erteledikleri söylenebilir. Özellikle çocukların okul öncesi dönemlerinde kadınlar ya evde çocuklarına bakmışlar ya da en iyi ihtimalle akademik çalışmalarına kısmi olarak devam edebilmişlerdir. Bilhassa biyolojik açıdan çocuğun anneye olan bağlılığı, bu hususta kadınların mesleki yaşamlarını doğrudan etkilemiştir. Oysa erkek akademisyenler kaç yaşında çocuk sahibi olursa olsunlar, iş hayatlarında herhangi bir erteleme yapmak zorunda değildirler. Erkeğin iş hayatına kesintisiz olarak devam ettirmesini, sahip olduğu biyolojik ve toplumsal rol ayrıca desteklemektedir. Hatta toplumsal bir kabul olarak kadınların mesleklerinden bağımsız olarak ev içi sorumlulukları ya da çocukların bakımı gibi görevleri üstlenmeleri, erkek akademisyenlerin kadın akademisyenlere kıyasla işlerine daha çok vakit ayırarak daha iyi odaklanmalarını sağlamaktadır. İşle ilgili etkenler genellikle toplumsal cinsiyete özgü şekillenmese de, ev-iş arasındaki çatışmada rol oynayan aile ile ilişkili etkenlerin her iki cinsiyet üzerinde her zaman aynı olmadığı görülmektedir. Geleneksel toplumsal cinsiyet rollerinin, örneğin çocuk bakımı gibi, ev görevlerini daha fazla kadınlara yüklemesi, ev-içi hayatıyla ilgili etkenlerin kadınların tutum ve hareketlerinde daha büyük etki oluşturmaktadır (Connel; 1998: Dalkılıç, 2015); Demir, 1997; Hacımirzaoğlu, Berktay, 1999; Voydanoff, 1988).

Buna karşılık, nadir de olsa istisnai durumlar söz konusudur. Kimi kadınlar, eşlerinden aldıkları destek ve onların özverisiyle mesleki hayatlarına ara vermeden devam edebilmişlerdir. Verilen cevaplara göre daha sonra detaylı olarak ele alınacaktır, fakat eşleri de kendileri gibi akademisyen olan kadınlar, mesleki hayatlarını yürütmekte ve ev hayatlarına dair sorumlulukların paylaşılmasında daha avantajlı konumda olduklarını belirtmektedirler.

Akademisyen kadınların gerek evlerinde üstlendikleri anne rolünün mesleki kimlikleri ile karıştırılması gerekse toplumsal cinsiyetlerinin gerektirdiği anne karakteri dolayısıyla profesyonel hayatlarında da kimi zaman onlardan bir anne ya da bir abla gibi davranmaları beklenmektedir. Bu beklenti kadınlar tarafından karşılanmadığında ise çoğu zaman ciddi bir sorunla yüz yüze kalınmaktadır. Akademisyen kadınlardan anne gibi davranmalarının beklenmesi yeri geldiğinde öğrenciler tarafından istismar noktasına varabilmektedir. Örneğin, öğrenciler erkek hocalarından talep bile edemedikleri anlayışa karşılık kadın hocalarından hem bu anlayışı talep etmekte hem de bu konuda hoşgörülü olmalarını cinsiyetleri dolayısıyla bir zorunluluk olarak görmektedirler. Böyle olmadı̆̆ı takdirde ise tepkilerini doğrudan göstermekte bir sakınca görmemektedirler. Sonuç olarak akademisyen kadın iş hayatında da anne kimliğinden kolay kolay sıyrılamamaktadır. 
Maalesef yukarıda bahsi geçen mevzu yalnızca öğrenciler ve akademisyen kadınlar arasında değil, yine kadın akademisyenlerin kendi aralarında çok daha ileri boyuta taşınabilmektedir. Bu soruya verilen kimi cevaplarda yeri geldiğinde bilimsel saygınlığın bile zedelendiği görülmektedir. Örneğin kimi zaman bir kadın akademisyenin erkek bir meslektaşına duyduğu mesleki saygı, hemcinsine duyduğu saygıya baskın gelebilmekte, ve bu dengesizliğin sebebinin her durumda maalesef yalnızca akademik birikim ile açıklanamadığı görülmektedir.

Kadınların akademik hayatını doğrudan etkileyen unsurlardan biri de nasıl bir ev-içi hayat yaşadıklarıdır. Buna ilişkin evli veya çocuk sahibi olup olmadıkları, eşlerinin meslekleri, eşlerinin meslekleri doğrultusunda ev-içi hayatta görev paylaşımları konuları gündeme gelmektedir. Bu doğrultuda görüşülen akademisyen kadınlara sırasıyla "Eşiniz, görev paylaşımında bulunarak ev hayatını sizin için kolaylaştırıyor mu?” ve "Eşinizin mesleği ev hayatınızı nasıl etkiliyor?” soruları yöneltilmiştir.

Evlilik hayatı, resmi bir müessesedir ve bu müessesenin sınırları yalnızca evlenen çifti değil, o çiftin aileleri ve sosyal çevrelerini de kapsamaktadır. Bunun yanı sıra kültürel olarak belirlenmiş cinsel kimliklerin toplumsal yaşamda en baskın olduğu alandır. Bu nedenle söz konusu cinsel kimliklerin gerektirdiği tavır ve tutumların bu çekirdek yapıda gözlemlenmesi beklenmektedir. Bir kadının bu açıdan eşinin mesleği ve bahsi geçen çekirdek yapıda nasıl davrandığı, kadının toplumsal rollerinin evlilik hayatlarında nasıl uygulandığının yanı sıra doğrudan ev hayatını, dolaylı olarak da mesleki hayatını etkilemektedir. İşte bu nedenle anketin "Ev-içi Hayat" bölümüne ait bu iki soruya verilen cevapların bir arada ele alınması uygun görülmüştür.

Buna binaen, çok ilginçtir ki Fen Bilimleri ve Mühendislik alanlarında profesör unvanına sahip akademisyen kadınlar eşlerinin ev hayatlarında destek olup olmadığıyla ilgili ne olumlu ne de olumsuz cevap vererek bu konuya ilişkin nötr bir tutum sergilemişlerdir. Bu nötr tutuma karşılık Sosyal Bilimler alanında çalışan aynı unvana sahip kadınlar çoğunlukla eşlerinin mesleğinin ev hayatlarını olumlu etkilediğini ifade etmektedirler.

Daha önce çok genel haliyle bahsedildiği üzere özellikle kendileri gibi eşleri akademisyen olan kadınlar gerek ev hayatlarında, gerekse profesyonel hayatlarında oldukça anlayışlı ve destekçi eşlere sahip olduklarını belirtmişlerdir. Fen Bilimleri ve Mühendislik alanlarında ve Sosyal Bilimler alanında kendileriyle görüşülen akademisyen kadınlar hemen hemen birbirlerine paralel görüşler belirtmişlerdir. Örneğin, ev-içi hayata dair, okul öncesi çocukların bakımının dönüşümlü olarak üstlenilmesi, ev işleri ve idaresinin paylaşılması gibi ödev ve görevlerde akademisyen kadın eşi tarafından desteklendiğini söylemektedir. Akademik hayata dair bilimsel bir projede görev alan kadının projedeki sorumluluklarını aksatmadan geç saatlere kadar çalışabilmesi, derslerini aksatmadan yürütebilmesi gibi sorumluluklarda ise erkeğin eşinin yükünü azalttığı örnekler mevcuttur. Bu örnekler göstermektedir ki, akademisyen erkekler meslekleri gereği eşleriyle çoğu zaman benzer problemlerle karşılaştıkları için rahatlıkla bu konular hakkında eşleriyle empati kurabilmekte ve sorunlara ilişkin çözüm üretebilmektedirler. Ayrıca tıpkı kadın akademisyenler 
gibi akademisyen eşleri de esnek çalışma saatlerine sahip oldukları için eşlerinin programına uygun bir düzenleme yapmaları mümkün olabilmektedir.

Eşlerinin mesleği zaman ve emek açısından daha talepkâr olan kadın akademisyenlerin bu denli şanslı oldukları söylenemez. Örneğin, böyle çiftlerin ev işlerinin idaresini eşit şekilde paylaşmaları genellikle mümkün olmazken, profesyonel yaşamlarında da eşlerine destek olmaları çoğu zaman söz konusu değildir. Dolayısıyla kadının iş hayatını düzenlemesi aile içi rol dağılımı ile doğrudan ilgilidir (Ersöz, 1999).

Henüz evlilik hayatını tecrübe etmemiş, gerek Fen Bilimleri ve Mühendislik alanlarında, gerekse Sosyal Bilimler alanındaki akademisyen kadınların çoğu, eşinin mesleğinin evlilik hayatını nasıl etkileyeceği ile ilgili kendilerine yöneltilen bu varsayımsal soruya cevaben olumsuz şekilde etkileyeceğini düşündüklerini belirtmişlerdir. Buradan çıkan sonuca göre eşin mesleği ne olursa olsun, evlilik hayatları üzerinde hiçbir şekilde olumlu bir etkisi olabileceğini düşünmemektedirler.

\section{Çalışma Saatlerinin Ev-içi Hayata Etkisi}

Sadece ev-içi hayatının, eşinin mesleğinin veya çocuk sahibi olmasının akademisyen kadının mesleğine etkisi değil, aynı zamanda kadının sürdürdüğü mesleki yaşamın ev-içi hayatına etkisi de önemli bir unsur olarak karşımıza çıkmaktadır. Örneğin esnek veya belirli çalışma saatlerine tabi olunması, kadının hem evdeki fiziksel varlığını hem de evde geçirdiği zamanın kalitesini açıkça etkilemektedir". Buna ilişkin "Akademi yerine çalışma saatleri belli olan, mesai saatleri dışında ekstra bir yükü olmayan bir işte çalışıyor olsaydınız bu durum ev hayatınızı nasıl etkilerdi?” sorusu yöneltilmiştir.

Yukarıda yöneltilen soruya verilen cevaplar arasında ağırlıklı olarak üç ana yaklaşım öne çıkmaktadır:

Birinci yaklaşıma göre akademik hayat özellikle zamanın planlanmasını ve yapılan çalışmaların -proje yönetim ve yürütücülüğü, tez yönetimi, idari ya da akademik kurullarda alınan görevlerin - kararlaştırılmış plana uygun olarak gerçekleşmesini güçleştirmektedir. Öte yandan akademik alanda iş saatlerinin işveren tarafından keskin bir şekilde belirlenmemesi, yine bu iş saatlerinin sınırlandırılmasını çoğu zaman imkânsız hale getirmektedir. Örneğin, yürütülmekte olan bir tez çalışması kapsamında öğrenciyle yapılan görüşme bazen yarım saat sürebildiği gibi bazen de dört saat veya daha fazla uzayabilmektedir. Böyle bir durumda, görüşme iki taraf için de tatmin edici bir nihayete ermeden sonlandırılamaz. Bu ise akademik çalışmanın zaman bağlamında kısıtlandırılmasını veya kontrol edilmesini zorlaştırmaktadır.

Yukarıda sözü edilen sınırlandırma ve kontrol zorlukları, ev hayatının düzenlenmesini de olumsuz yönde etkilemektedir. Örneğin, birtakım akademik görevlerin -kitap, makale gibi akademik

4 Kadının ev ve iş yerinde geçirdiği saatleri verimli bir şekilde düzenlemesine ilişkin daha detaylı bilgi için şu esere başvurulabilir: Peggy A. Pritchard (2006), Success Strategies for Women in Science: A Portable Mentor, London: Elsevier, 
yayınların yapılması, bilimsel toplantılara yapılan hazırlıklar, projelerin tamamlanması, derslerle ilgili materyallerin hazırlanması, tez, ödev ya da sınav kâğıtlarının okunması - belirli bir zamanda bitirilmesi ya da teslim edilmesi gerekmektedir. Ancak bahsi geçen görevlerin, aktif çalışma saatleri içerisinde iş yerinde tamamlanamaması sonucu, bitirilmesi gereken vakte yetişmesi için çalışmanın evde geç saatlere kadar devam etmesi zorunludur. Ayrıca işin zamanında bitirilmesi zorunluluğu, akademisyen kadın üzerinde ruhsal baskıya neden olmakta ve işlerin bitirilemediği ya da zamanında yetiştirilemediği durumlarda ise tatminsizlik duygusunu doğurmaktadır.

Akademik çalışmanın kadının hem iş hem de ev hayatını bu kadar kapsar nitelikte olması, onun aile hayatını düzenlemesini olumsuz yönde etkilemektedir. Bu nedenle mesai saatleri işveren tarafından kesin hatlarla belirlenmiş başka bir iş, bu yönüyle akademik hayata göre daha tercih edilebilir durumdadır. Çalışma saatleri belirli olan bir işin, kadını iş dışındaki günlük hayatında olabildiğince özgür bıraktığı için kadının eve ayırdığı vakti hem daha geniş hem daha kaliteli kılabileceği düşünülmektedir.

İkinci bakış açısına göre en fazla vurgulanan nokta, kadının kendi zamanını koşullar el verdiği ölçüde kendisinin ayarlayabilmesidir. İş hayatındaki esnekliğin ev-iş çatışmasını azalttığı iddia edilmektedir. Örneğin, evden çalışmak gibi oldukça esnek olan bir iş, kadının evdeki rolü ile profesyonel rolü arasında kaydırmalar yapmasına müsaade edecek, bu sayede zamanını daha iyi kontrol etmesini sağlayacaktır (Ngo, 1992). Örneğin derslerinin hangi gün ve saatlerde olacağını, öğrenciyle görüşme programını, üniversitede bulunacağı vakitleri, imkân dâhilinde kendisinin tasarrufundadır. Ancak bu saatlerin esnetilebilir olmasının her durumda bir avantaj olacağı sanılmamalıdır. Kadınlar, yeri geldiğinde kendi vakitlerinden feragat ederek, kendi çalışmalarını herkesin uyuduğu ya da henüz uyanmadığı vakitlere taşıyarak eş ve çocuklarına zaman yarattıklarını belirtmektedirler. Bu ise, kadın akademisyenleri erkek meslektaşlarından ayıran bir başka nokta olarak karşımıza çıkmaktadır.

Yanıtlardaki en belirgin üçüncü bir bakış açısına göre ise akademisyen kadın, çalışma saatlerinin nasıl düzenlendiğinin ya da hangi mesleği seçmiş olduğunun ev-içi hayatı üzerinde herhangi bir etkisi olmayacağını düşünmektedir. Dahası kişinin kendisinin ve evliliğinin yapısına bağlı olarak, mesleği ya da çalışma saatleri nasıl düzenlenirse düzenlensin, ev düzenini kendisinin kuracağını belirtmektedir. Dolayısıyla kadın, koşullar ne olursa olsun ailesi ve çalışma hayatı arasında bir denge gözetecektir.

Çalışma saatlerinin işveren tarafından belirlendiği bir işte çalışmanın ev-içi hayata etkisi ve yaratacağı olası avantaj veya dezavantajlar konusundaki bu birbirine karşıt iki görüşün yanı sıra çalışma saatlerinin ev-içi hayatı ve ebeveynlik rolleri üzerinde negatif ya da pozitif bir etkisi olmadığını dile getiren bu üçüncü bakış açısıyla paralel bir görüş olarak Prof. Dr. Emine Gönen, Doç. Dr. Şengül Hablemitoğlu ve Uzm. Arş. Gör. Emine Özmete tarafindan kaleme alınan "Akademisyen Kadınlar” adlı çalışma örnek verilebilir. Bu çalışmaya göre, akademisyen kadınlar, ebeveyn olarak kendilerine ilişkin tanımlamalarında olumlu görüş bildirmektedirler. 
Kısaca, kendilerini bir ebeveyn olarak yeterli, aktif ve başarılı olarak görmektedirler (Gönen, Hablemitoğlu, Özmete, 2004).

Kimisi de bu konuda hakkında hiç düşünmediklerini belirterek hiçbir kanaat belirtmemiştir.

\section{Sosyal Hayat}

Kadınların kişisel gelişimi, buna bağlı olarak yaptıkları tercihler ve aldıkları kararlar, onların yaşam biçimlerini, sosyal çevrelerini ve hatta akademik hayatlarını da etkilemektedir. Aynı zamanda belirlenen bu sosyal çevre, kimlerle arkadaşlık edileceğini, kimlerle iletişim içinde olunacağını içermektedir. Örneğin, kişinin hangi üniversitede eğitim aldığı, eğitim aldığı üniversitede yaptığı konaklama seçimi, üniversitede görev ya da yer aldığı sosyal ve kültürel aktiviteler, birlikte olacağı sosyal çevreyi seçmesi için imkân tanır (Akşit, 2012). Seçilen bu sosyal çevre, zaman içerisinde bağlar kopsa bile çoğu zaman onun hayatındaki uzun ömürlü beraberliklerin, dostlukların belirlenmesinin arka planında aktif rol oynamaya devam eder. Üniversite hayatının kişinin yaşamında bu kadar etkin olması, akademisyen kadınların tecrübelerinde de gözlemlenmektedir. Bu nedenle bu bölümde "Sosyal çevreniz de akademisyen ağırlıklı mı?” sorusunun yöneltilmesindeki temel amaç, kazanılan deneyimin akademisyen kadınların profesyonel ya da aile hayatlarında bakış açıları üzerindeki etkilerinin belirlenmesidir. Böylece hali hazırda profesyonel hayatı ve ev-içi hayatı hakkında bilgi sahibi olduğumuz akademisyen kadının yaşamını bir bütün olarak değerlendirmek mümkün olmuştur.

Fen Bilimleri ve Mühendislik alanlarında çalışan akademisyen kadınlar kadar Sosyal Bilimler alanında çalışan akademisyen kadınlar arasında da henüz mesleki hayatının başında olanların, yukarıda tanımlanan sosyal çevreyi sadece üniversite ve akademisyenlerle sınırlandırmadıkları görülmektedir. Bu kadınların akademik hayatın dışında da aktif olarak katıldıkları, iletişimde bulundukları bir çevreden bahsedilebilir. Buna karşın, akademik yaşamdaki geçmişi daha uzun olan akademisyen kadınlar ise sosyal çevrelerinin de yine akademisyenlerden oluştuğunu belirtmektedirler.

Bu iki seçim biçimi arasındaki farkın örtük ve açık pek çok sebebi olabileceği gibi, bunların arasından öne çıkan akademik hayatın, kişinin sosyal hayatını da kapsayıcı hale gelmesidir.

Ancak burada kadınların tercihi değerlendirilirken, çıkan sonuç sadece zorunlu bir aradalık ya da sınırlı zamana sahip olmanın getirdiği bir mecburiyet olarak anlaşılmamalıdır. Akademik hayatın daha kapsayıcı olması ve kişinin beraberinde akademisyen ağırlıklı bir sosyal çevreye sahip olması, tamamen kişinin kendi tercihiyle ilişkilendirilmesi gereken bir durumdur.

Sosyal hayat, kişinin sosyal çevresinin yanı sıra boş zamanlarını nasıl değerlendirdiğiyle de şekillenmektedir. Bu bağlamda, kişinin herhangi bir hobiye sahip olması, onun ufkunu, bilgi ve becerilerini geliştirmesine imkân tanır. Aynı zamanda boş zamanlarının bedensel ve zihinsel emek sarf edilmesi suretiyle keyifli bir şekilde doldurulmasını sağlamaktadır. Burada hobilere vakit ayrılabilmesi için dikkat çeken en önemli husus, kişinin yeteri kadar boş zamana sahip olması gerekliliğidir. 
Yöneltilen “Akademik çalışmalarınız dışında başka hobiler edinmeye vakit bulabiliyor musunuz?” sorusuna verilen cevaplar göstermektedir ki, Fen Bilimleri, Mühendislik ve Sosyal Bilimler alanında çalışan akademisyen kadınların büyük çoğunluğu hobilerine vakit ayıramamaktadırlar. Bir katılımcının ifadesiyle "sosyal yaşam, aile-ev-üniversite üçgeni”nde şekillenmektedir. Bir başka katılımcı ise çok farklı bir noktaya işaret etmektedir. O, "İstanbul çok zor ve zamanı tüketen bir kent, mesafelerin uzaklığı ve trafik zamanımı alıp götürüyor” diyerek yaşadığı şehrin, sosyal hayatını nasıl etkilediğini dile getirmektedir.

Öncesinde dans etmek, bahçe işleriyle meşgul olmak ya da bir müzik enstrümanı çalmak gibi hobilere sahip olmalarına rağmen, evlilik hayatlarının başlamasıyla birlikte hobilerine vakit ayıramadıklarını, özellikle çocuk sahibi olmalarından sonra ise hobilerine gerekli olan vaktin sağlanmasının imkânsız hale geldiğini ifade etmişlerdir. Boş vakitleri olduğunda ise bu boş vakitlerini çocuklarıyla geçirmeyi tercih ettikleri için kendi bilgi ve becerilerinin geliştirilmesini gönüllü olarak ikinci plana bıraktıklarını söylemektedirler.

Bu soru bazı akademisyen kadınlar tarafından, bilhassa bu bölümün çalışma saatleri belirli bir işe sahip olmanın ev-içi hayata etkisinin sorgulandığı 4. sorusu ile alakalandırılarak cevaplanmıștır. Buna göre çalışma saatleri belirli işlerde çalışmaları halinde, kadınlar hem kendilerine hem de aile hayatlarına daha çok vakit ayırabileceklerini düşünmektedirler. Örneğin, işin eve taşınması gerekmeyen işlerde çalışan kadınların daha fazla boş vakti olacağından kendi hobilerine daha fazla zaman ayırabileceklerini düşünmektedirler.

\section{Sonuç ve İyileştirme Önerisi}

Farklı disiplinlerde akademik kariyere sahip olan kadınlar, birbirlerininkine benzer sorunlarla karşılaşmaktadırlar. Fırsat eşitliği ve bilimsel ve akademik yönetime katılım, akademisyen kadınların hayatını zorlaştıran en önemli meselelerden biridir. Örneğin Tablo.6'da verdiğimiz idari görevde yer alması bilgisine göre çok az sayıda kadının yönetime katıldığı apaçık görülmektedir. Kadının yönetime katılımıyla ilgili yapılan son dönem çalıştaylarda da kadın yöneticinin teşvik edilmesi daima vurgulanmış ve çözüm önerileri getirilmiștir (YKLÇ, 2012; YÖK, 2015). Bu nedenle burada yapılan öneriler her şeyden önce yasal düzenlenmelerle desteklenen öneriler olacaktır:

1- Özellikle fırsat eşitliğini sağlamak için gerek akademik gerekse bilimsel kurullarda en az bir kadın bulunması zorunluluğu getirilmesidir. Gerekirse bu pozitif ayrımcılık çerçevesinde bir yönetmelik maddesi ile desteklenerek yasallaştırılmalıdır. Böylesi bir katılıma yön verme, mevcut durumu iyileştirme açısından önemli bir adım olacaktır.

Yine profili betimlemeye yönelik sunulan Tablo.5’e göre hemen hemen bütün farklı akademik birimlerde kadınların ev-içi hayatlarıyla akademik hayatlarını mümkün olduğunca bir arada yürütmeye çaba sarf ettikleri açıktır. Bahsi geçen ev-içi hayat, kimi akademisyenler için bir veya daha fazla çocuk sahibi olmayı da içermektedir. Bu nedenle çocuk sahibi olmuş akademisyen 
kadınların mesleki çalışmalarını sürdürebilmeleri ve akademik hayattan tamamen kopmamaları için birtakım düzenlemeler getirilmelidir.

2- Örneğin, çocuk sahibi olmuş kadınların mevcut durumlarına göre yarı zamanlı çalışmaları, yahut çalışma saatlerinin esnek olması sağlanmalıdır. Bu imkanın, bölüm, fakülte veya enstitü yöneticilerinin keyfiyete bırakılmaksızın yine yasal düzenlemeyle güvence altına alınması gerekmektedir.

Akademik hayatı yüksek lisans öğrenciliğinden profesörlüğe ulaşan süreçte batılı hemcinslerine oranla daha düşük engelli asmak zorunda olmasına karşın Türkiyedeki kadın akademisyenler yönetsel kademelere uzak durmayı tercih etmektedir. Bu uzak durma tavrı ve üniversitelerde eril bir kültürü ve yerleşik erkek egemen yapıları güçlendirmektedir. Oysa Sağlamer, Tan ve Çağlayan’ın yaptığ 1 proje içindeki 7 üniversitede de yönetsel dağılımlara ilişkin karşılaştırmalı veriler, bu yönetsel uzaklığın kadın rektörlerin görev yaptığı dönemlerde kadın yöneticilerin lehine değişebildiğini ve yönetsel pozisyonlarda kadın varlığının gözle görülür bir artış gösterdiğini ortaya koymaktadır (Sağlamer, Tan ve Çağlayan, 2013). Öte yandan Bu çalışma ayrıca göstermektedir ki; kadın yöneticinin mevcut durumu düzeltmek, yani akademisyen kadınların yönetime katılması ve karar verici pozisyonda olmasını sağlamak için yine kadın yöneticiye ihtiyaç duyulmaktadır. Sonuç olarak kadınlar, yine kendi elleriyle durumu düzeltmek üzere zorunlu olarak yönetime katılmalıdır.

3- Kadın rektör sayısı artırılmalı, gerekirse pozitif ayrımcılık ilkesi ile belirli orada kadın rektör ataması yasal olarak güvence altına alınmalı.

Ayrıca burs veya benzeri, süresi kısıtlı programlara çocuk sahibi kadınlar için 2 yıl kadar ek süre verilebilir. Yukarı önerilen bu iyileştirmeler, akademik hayatta, kadınları erkeklerle mesleki açıdan kısmen de olsa fırsat eşitliği ve bilimsel ve akademik yönetime katılımları için eşit duruma getirebilir.

4- Kadınlara, özellikle çocuk sahibi olan kadınlara yasal düzenleme sağlanarak, burslarının veya yaş sınırı olan programlarda ek süre tanınmalıdır.

Bütün bunların yanı sıra özellikle akademik alanda iş gören kadınlar hakkında yapılacak her türlü çalışma, onların daha yaşanabilir ve tercih edilir bir akademik alana sahip olmalarına yardımcı olacaktır. Bu amaç doğrultusunda, kadınların akademik alanda ya da daha geniş bir perspektifle profesyonel alanda sorunlarına yönelik çalışmaların desteklenmesi önem arz etmektedir. Kadının emeğinin hak ettiği değeri görememesi adaletsizliği desteklemektedir. Bu durumun düzeltilmesi yeni yasa ve yönetmeliklerin koyulmasını gerekli kılmaktadır. Kadınların eşitliğinin sağlanması ancak öncelikli davranılmasıyla mümkündür. (Wendy, 1996).

Sonuç olarak kadına verilen akademik destek sadece bireysel veya belirli bir grubun yararına olan bir destek değildir. Aksine kadın akademisyenler tarafından yetiştirilen öğrenciler göz önünde bulundurulduğunda yapılan her iyileștirme doğrudan ülke genelinde katkı sağlayan bir iyileştirme olacaktır. 


\section{Kaynakça}

Akşit, E. (2012) Kızların sessizliği: Kız enstitülerinin uzun tarihi. İstanbul: İletişim Yayınları.

Anon, (2017) Türkiye'de Kadın 2017. T.C. Aile ve Sosyal Politikalar Bakanlığı, Kadının Statüsü ve Sorunları Genel Müdürlüğü, Ankara

Benhabib S., J. Butler, D. Cornell, N. Fraser (2008) Çatışan Feminizmler, çev. F.E. Sezer, İstanbul: Metis.

Belkıs, Ö. (2016) Anneliğin Akademik Kariyer Gelişimine Etkileri Üzerine Nitel Bir Araştırma, Eğitim ve Ögretim Arastırmaları Dergisi, C:5, S:4, 2016, S. 250-263.

Brezinka, W. (1971) Von der Pâdagogik zur Erziehungswissenschaft, Weinheim, Basel: Beltz Verlag.

Butler, J. (2008) Cinsiyet Belası, İstanbul: Metis.

Connel, R. W. (1998) Toplumsal Cinsiyet ve İktidar, çev. C. Soydemir, İstanbul: Ayrıntı.

Dalkılıç. O. S. (2015) Çalış Anne, Nobel Yayınları.

Demir, Z. (1997) Modern ve Postmodern Feminizm, İstanbul: İz.

Dökmen, Z. Y. (2016) Toplumsal Cinsiyet - Sosyal Psikolojik Açıklamalar, Remzi Kitabevi,Istanbul.

Dayığlu, Meltem - Kasnakoğlu, Zehra (1997) "Kentsel Kesimde Kadın ve Erkeklerin İşgücüne Katılımları ve Kazanç Farklılıkları” METU Studies in Development, Vol. 24, No: 3, s. 329-361.

Ersöz, A. G. (1999) Cinsiyet Rollerine İliş̧kin Beklenti Tutum Davranışlar ve Eşler Arası Sorumluluk Paylaşımı, Kültür Bakanlığı Yay.

Frone, M.R., M. Russell, M.L. Cooper, Antecedents and Outcomes of Work-Family Conflict: Testing a Model of the Work-Family Interface, Journal of Applied Psychology, 1992, Vol. 77, No. 1, 65-78.

Gönen, E., Ş. Hablemitoğlu, E. Özmete (2004) Akademisyen Kadinlar, İstanbul: Toplumsal Dönüşüm. Hacımirzaoğlu, A., Berktay (der.) (1999) 75 Yılda Kadınlar ve Erkekler, İstanbul: Tarih Vakfı, İş Bankası, IMKB.

Kandiyoti, D. (1997) Cariyeler, Bacılar, Yurttaşlar, İstanbul: Metis. Kantor, P., H. Jarvis, J. Clocke, (2015) Kent ve Toplumsal Cinsiyet, Dipnot Yayınları. Madeline E. Heilman, Sex Discrimination and the Affirmative Action Remedy: The Role of Sex Stereotypes, Journal of Business Ethics, June 1997, Volume 16, Issue 9, pp. 877-889. Ngo, H.Y. (1992) "Employment status of married women in Hong Kong”, Sociological Perspectives, 35, 475-488.

PetraHofman: "WeiblicheArbeitswelten in der Wissenschaft, Frauen an der PreußischenAkademie der wissenschaftenzuberlin 1890-1945, transcriptVerlag, Bielefeld, 2011. Özdemir, D. ve Tanyıldı, Z. E. (2011) Bilim Kadını Olmak: Bilimsel İsgüüünde Kadın ve Cam Tavan. Türkiye Ekonomi Politikaları Araştırma Vakfi.

Peggy A. P. (2006) Success Strategies for Women in Science: A Portable Mentor, London: Elsevier.

Schein, V. E. (1975) Relationships Between Sex Role Stereotypes and Requisite Management Characteristics Among Female Managers, Journal of Applied Psychology, 60(3), 340-344.

Sağlamer, G., Tan, M. ve Çağlayan, H. (2013) Türk Yükseköğretiminde Kadın Katılımı Üzerine Bir Araştırma, Türkiye’de Bilim, Mühendislik ve Teknolojide Kadın Akademisyenler Ağı, İstanbul.

Spence, J.T., R. Helmreich (1972) The attitudes toward women scale: An objective instrument to measure attitudes toward the rights and roles of women in contemporary society, Catalog of Selected Documents in Psychology, 2(66).

StatistischesBundesamt (İstatistik Kurumu): "Auf dem wegzuGleichstellung? Bildung, arbeitundSoziales UnterschiedezwischenfrauenundMånnern”, StatistischesBundesamt, Wiesbaden, 2014.

Ulrich H. (1982) AnwendungsorientierteWissenschaft, Swiss Journal of Business Research and Practice, VOL.36, No.Ipp. 1-10, Nomos Verlagsgesellschaft. 
Voydanoff, P. (1988) Work role characteristics, family structure demands, andwork/family conflict, Journal of Marriage and the Family, 50, 749-761. YKLÇ (Yükseköğretimde Kadın Liderliği Çalıştayı), (2012). Yükseköğretimde kadın liderliğini geliştirme ve güçlendirme çalşstayı raporu. Düzce Üniversitesi, Düzce. YÖK (Yüksek Öğretim Kurumu), (2015) Toplumsal Cinsiyet Eșitliğine Duyarl Üniversite Çalıştayı.

YÖK-Yüksek Öğretim Bilgi Yönetim Sistemi. https://istatistik.yok.gov.tr .

Weber M. (1995) Wissenschaft als Beruf, Stuttgart: Reclam. Wendy, Mc.E., (1996) Sexual Correctness: The Gender-Feminist Attack on Women, McFarland \& Company Inc. Publishers, Jefferson, North Carolina. 
